\title{
Marketed as Approved Drug Product Manufactured Exclusively for Private Label Distributor
}

National Cancer Institute

\section{Source}

National Cancer Institute. Marketed as Approved Drug Product Manufactured Exclusively

for Private Label Distributor. NCI Thesaurus. Code C95600.

A marketing category specifying that an approved drug product is manufactured and packaged exclusively for a Private Label Distributor, and not otherwise marketed by the drug product's manufacturer. 